\title{
A NEWER REALM OF POETRY: WHITMAN AND AI QING
}

\section{GuIYOU HUANG}

IN THE PAST SIX DECADES, the work of the Chinese poet Ai Qing (19101996) has attracted an enormous amount of attention, and the foreign impact upon his poetry has not gone unnoticed. His admirers and critics have sometimes mentioned, often in passing, Walt Whitman's influence on him, suspecting some connecting links between the two poets but failing to elucidate them. This essay attempts to measure the extent of Whitman's impact on $\mathrm{Ai}$; it will also show how $\mathrm{Ai}$ incorporates the prose element into poetry, thereby opening up a new realm for twentieth-century Chinese poetry.

That Ai resembles Whitman in style and subject matter is indisputable. According to Li Yeguang, Whitman's Chinese biographer, Whitman's style can be seen in many of Ai's poems, including his most famous piece, "Dayanhe, My Nanny," and other well-known poems such as "Snow Falls on the Land of China," "The Bugler," "Lamenting for Paris," "Times," and "The Prairie Fire."1 In a broader perspective, though, $\mathrm{Ai}$ is also reminiscent of some European writers, especially Baudelaire, Rimbaud, Verhaeren, Yessenin, Mayakovsky, and, to a more limited extent, the Chilean author Neruda. It is notable that all these poets relate to Whitman in some way while also sharing stylistic similarities among themselves.

Ai seems to have the most affinity, however, with Whitman and Mayakovsky, both of whom he admired greatly. In the autumn of 1933, Ai published two prose poems, and in the first piece, entitled "The Sailor's Tobacco Pipe," he writes, "If I am to paint a picture of Whitman or Mayakovsky, I will definitely add a sailor's pipe to their broad lips, regardless of whether or not they had a sailor's tobacco pipe in their lifetimes." Ai then goes on to explain why he wants to see both poets smoking a pipe: "For the mouth to be wide open like oceans in order to read poetry to the masses, in the painting I have to have a sailor's pipe, which symbolizes cosmopolitan feelings, and the white smoke of which flows through the world like the freshest poetry." 2 This short prose poem lightheartedly and yet sincerely expresses Ai's admiration for Whitman and Mayakovsky. As the critic Sun Yushi points out, even at the beginning of his career, Ai revealed a profound affinity 
with the two poets: "The images of Whitman and Mayakovsky smoking a pipe can be regarded as a specific manifestation of Ai Qing's own innermost artistic aspirations." 3

Like Whitman, as Eugene Eoyang observes, "Ai Qing is able to find the meaningful in the commonplace." And like Whitman, who proclaimed in his 1855 preface to Leaves of Grass that "The genius of the United States is . . always most in the common people," Ai identifies with the common people and emphasizes togetherness. However, as Eoyang rightly points out, though Whitman is the most apposite influence on $\mathrm{Ai}$, there is one significant difference: "Ai Qing lacks Whitman's all-encompassing ego. Where Whitman spoke as the embodiment of the people, the poet as the people, Ai Qing has assumed a more modest stance: he has been content to be, from time to time, a poet of the people." Whitman is notorious for his egotism, which is exactly what is missing in $\mathrm{Ai}$, who recognizes the necessity of individual freedom and yet expresses more concern for the welfare of others and his nation. In China, especially during the third quarter of the twentieth century, there could be no higher compliment than to be named an "artist of the people," and, despite Whitman's egotism, the phrase has long been associated with him in China. Tian Han, author of the first essay on Whitman in China, was called "the artist of the people," an epithet that echoed his own labeling of the American writer as "poet of the common people" in a 1919 essay. ${ }^{7}$ It is fitting, then, that on August 26, 1991, when an international conference on Ai's works was held in Beijing, He Jingzhi, then acting minister of culture, delivered a speech praising $\mathrm{Ai}$ as "an outstanding artist of the people."

It is not surprising that Ai lacks Whitman's inflating ego; in this regard, he is merely typical of almost all Chinese writers and intellectuals between 1949, the year the People's Republic was founded, and 1978, when China officially adopted the "Open-Door" and reform policies. During those three decades writers were made subservient to political needs and were forced to conform to the communist dogma that downplays the importance of individualism in favor of collectivism. Ai's own modesty no doubt also contributed to the wide reception of his works. Ai seldom uses first-person pronouns in his poetry unless it is absolutely necessary (and even then only when he is clearly being modest about himself). While Whitman never forgets his "workmen and workwomen," he also never forgets himself; in fact, he often emphasizes his own presence. Ai, on the other hand, prioritizes the people and places them at the center of his poems, while hiding the self behind a stereotypical Asian modesty. But Ai would not be considered a "new" poet had he rejected foreign ideologies such as American individualistic democracy and Soviet socialism, and had he continued on the path of traditional Chinese poetry. It is important to understand, though, that 
Chinese cultural and intellectual traditions emphasize concern for the country more than for the self, and authors - who are generally respected in China as the conscience of society-are urged to write about the society and its people. Writing about the self is permitted only insofar as the author can demonstrate how he or she has progressed from an ideologically backward writer to a patriotic, socialist, revolutionary writer, loyal to the communist party, who unconditionally accepts the doctrines of the ruling ideology and adheres to Marxist teachings.

Whitman and Ai are clearly products of their respective eras and societies, and, as Eoyang notes, "both are moral poets, both have large sympathies, both are enormously touched by the lives of other human beings." In Whitman's words, the poet "is the arbiter of the diverse and he is the key. He is the equalizer of his age and land ... he supplies what wants supplying and checks what wants checking." Whitman portrays the poet as playing universal roles and as having an office in all times: "If peace is the routine out of him speaks the spirit of peace, . . . In war he is the most deadly force of the war. Who recruits him recruits horse and foot ... he fetches parks of artillery the best that engineer ever knew." 10 Ai upholds similar views on the function of poetry in peace and war. When he was imprisoned by the Nationalist government from 1932 to 1935 for left-wing activities, he protested and fought what he called "the unjust world" with poetry, the only weapon left to him when he lost his freedom. At this time, he invoked foreign poets like Apollinaire, Baudelaire, and Rimbaud as he satirized and denounced the oppressive rule.

More significantly, in 1937, the year the Sino-Japanese War broke out, $\mathrm{Ai}$ started to write anti-Japanese poems. In addition to writing his own poems, Ai edited The Poetry fournal, a widely read magazine published in the 1940s in Yan'an, headquarters of the communist-led antiJapanese forces. There Ai published Whitman's poems, translated by various Chinese poets, ${ }^{11}$ including "When Lilacs Last in the Dooryard Bloom'd," "Song of the Open Road," "O Captain! My Captain," and "I Sit and Look Out." "Song of the Open Road"-with its articulation of hope, advocacy of democracy, and chant of the liberation of the spiritwas much in tune with the "New Democratic Revolution" going on in communist-controlled areas. Ai's own poem, "Human Skin," was written during this time period; it concerned Japanese atrocities perpetrated against Chinese civilians, and it shocked so many Chinese readers and soldiers that it was credited with contributing greatly to the anti-Japanese sentiment throughout the country. Ai thus assumed the role of a warrior-poet, one who fought not with swords but with words.

This function of poetry, to produce ideology as a catalyst to emotional and physical forces, was admirably realized in both Whitman and 
Ai. As Etienne Balibar and Pierre Macherey point out, "The ideological effects of literature . . materialise via an identification process between the reader or the audience and the hero or anti-hero, the simultaneous mutual constitution of the fictive 'consciousness' of the character with the ideological 'consciousness' of the reader." Hence the power of literary writings such as "Human Skin" and Whitman's "Beat! Beat! Drums!" The effect they produce is "to provoke other ideological discourses which can sometimes be recognised as literary ones but which are usually merely aesthetic, moral, political, religious discourses in which the dominant ideology is realised." ${ }^{12}$ So once a new ideology, fundamentally Marxist and espoused by the ruling class, is instituted, any literary, political, and cultural counter-currents are censored, punished, and ultimately silenced. Ai himself fell victim to the weapon called writing: when the anti-rightists campaign started in 1957, his works were found to express antisocialist, rightist views, and essays were written attacking his poetry as well as his person. As a result, he became what he himself called "a spittoon." The criticism was so deadly that he was silenced for twentyone years, from 1957 to 1978 , when the central government started to loosen control over writers throughout the country.

But even during the period he was silenced, Ai never lost his regard for Whitman. If anything, his respect for Whitman deepened around what Ai perceived to be their mutual affection for the afflicted, the poor, the weak, and the voiceless. There is a similar delicacy and sympathy in both poets, as we can see in their surprisingly similar treatment of birds in pain. Ai's "Water Birds" briefly and yet powerfully describes the unexpected injury of one bird by a hunter while the other bird flees in fright, leaving the injured bird struggling on its own to gain a hiding place amid crevices of stones, sadly and hopelessly waiting for the return of its companion. Ai writes,

At the moment

Amidst crevices of stones

With its own beak

The bird caressed its wound,

And in its sorrowful moaning of solitude

Expecting the return of its soul mate. ${ }^{13}$

Whitman's "Out of the Cradle Endlessly Rocking," of course, presents a sad, moving song of the "he-bird" after the mysterious disappearance of the "she-bird" that had been nesting. The boy in the poem seems to understand the lamenting song of the he-bird and sympathizes with him. "Water Birds" and "Out of the Cradle Endlessly Rocking" both evince deep sympathy toward the unfortunate, the wounded bird in the former and the surviving he-bird in the latter, though Whitman's piece is ultimately more about a boy's becoming a poet by facing death. In these pieces both poets praise companionship, and both emphasize 
togetherness. The disappearance or possible death of the she-bird somehow becomes an inspiration to Whitman, and this childhood experience marks a turning point in his life. $\mathrm{Ai}$, on the other hand, stops short of a tragic ending, and the last line of his poem leaves a ray of hope for the return of the escaped bird.

The broadness and openness of Whitman's mind in "Song of the Open Road" also clearly left its mark on some of Ai's pieces. One noteworthy example is the latter's "Highway," the beginning lines of which read: "Like Americans walking on California's roads, / I march on the new highways on China's western plateau." 14 But it is not the invocation of Americans in California that makes this poem Whitmanian, it is the lighthearted tone and carefree spirit that define the kindred relationship of the two. In Whitman's case, the poet's robust optimism and his sense of the liberated self are clear from the beginning:

Afoot and light-hearted I take to the open road,

Healthy, free, the world before me,

The long brown path before me leading wherever I choose. ${ }^{15}$

$\mathrm{Ai}$, walking the broad and smooth highway in China, also indulges in the delicious freedom of the open road as he chants:

My soul thus liberated

And my lungs breathing fresh air,

The pupils of my eyes dilated for the vistas;

My feet, though lame from tiredness, joyfully continue the march on earth. ${ }^{16}$

In both pieces, the open road is a symbol of freedom, freedom of the body as well as of the mind; and both show a happy union of humanity and nature as the poets walk the country roads. The road and the highway provide the poets an opportunity to contact nature which in turn creates an exhilarating sense of liberation and freedom. Clearly this freedom in the open fields is not readily available in cities and densely populated urban areas. Not only do the two poets express their delightful feelings at their physical contact with nature as represented by the road, they also convey a profound admiration for the freedom gained through union with nature and through dissociation-however brief-from human society.

As these examples demonstrate, Ai picked up many things from Whitman-sympathy, freedom, dedication to the common people. But there is one more quality they share that must be considered, for this is the element with which Ai made his poetry new and different from traditional Chinese poetry that adheres to strict meters and rhymes. We will call this the prose element. Whitman is credited for breaking the forms of conventional poetry and for introducing into poetry elements 
intrinsic to prose, such as the use of long, irregular lines and a general disregard for meters and rhymes. In "The Prosy Beauty of Poetry," Ai writes, "The one important reason why I like Whitman, Verhaeren, and many other modern poets, including Mayakovsky, is because they ushered poetry into a newer realm and raised it to a higher plane, and because prose is intrinsically more beautiful than verse." Ai goes on to assert, "We must make all efforts to carry on the revolution started by Whitman, Verhaeren, and Mayakovsky, and we must mold poetry into something that adequately meets the needs of the new era-meet them with new forms." 17

In his poetry, Ai carried out new prose experiments that were based on his study of Whitman. The following lines from Ai's "To the Sun," written in the late 1930s, not only mention Whitman but illustrate his style:

Whitman, inspired by the sun,

And with a mind broad as oceans,

Wrote poetry as broad as oceans.

The rising sun shines on our heads

That have long drooped and never been raised;

On our cities and villages that we have long inhabited and yet are subdued by unjust powers;

On our fields, rivers, and mountains which, for unremembered periods of time, have crawled and writhed with tormented souls. ... ${ }^{18}$

These lines show a definite disregard for the classical style and reveal prose characteristics commonly seen in Whitman's poems.

In the Chinese historical and literary contexts, "new" poets started to write "new" poetry in the mid-1910s, and especially after 1919 when the new culture movement culminated in the May 4th movement that prepared China for a series of revolutions in politics, literature, culture, and social life. Chinese historians and scholars and writers have generally labeled post-1919 literature written in the vernacular as "new" literature, with "new" most often applied to poetry. But few have bothered to work out a historically specific definition of the term. A close reading of Guo Moruo and $\mathrm{Ai}$ Qing, the most representative and typical of twentieth-century Chinese new poets, clearly points to one fact: the "newness" in Chinese "new" poetry does not only refer to new forms and new contents, but also to new creative methods.

In his preface to An Appreciative Companion to Ai Quing's Famous Poems, editor Niu Han discusses the poet's works in the broader context of Chinese new poetry. In his view, Ai's poetic practice allowed Chinese new poetry to achieve unprecedented development. Robert Payne also thinks that Ai was "the first to perform the essential and surgical operation of completely separating Chinese poetry from its roots in the past and transplanting them in the soil." ${ }^{19}$ This assertion, though it over- 
looks Guo, is largely accurate and very much in keeping with $\mathrm{Zhu}$ Hongxing's remark that, "Ai Qing was the first poet to recognize and give articulation to 'the prosy beauty' of poetry," 20 an issue Ai propounds in his own "The Prosy Beauty of Poetry." Niu, on the other hand, stresses Ai's love of simplicity and his insistence on using the vernacular language, both of which constitute a "crucial element" that creates a "prosy beauty" in poetry. However, he is also careful to add that "prosy" beauty does not mean the "prosification of poetry."21 "Dayanhe, My Nanny," written in prison in 1933, with which Ai made his debut, demonstrates this so-called "prosy" beauty:

Dayanhe, to make a living,

After using up her milk to feed babies,

Started to work with her two arms that had carried me;

With a smile she washed our clothes,

With a smile she sliced frozen turnips,

With a smile she cleaned pigs' troughs,

With a smile she fanned the stove fire that stewed meat,

With a smile she went to the square with a basket

to spread beans and wheat grains for sunshine.

Dayanhe, to make a living,

Started to work with her two arms that had carried me. ${ }^{22}$

Repetition is conspicuous here, and Payne sees this trait as a weakness in Ai's poetry ${ }^{23}$ - a fault that many readers find in Whitman, too.

Niu Han believes that Ai naturally took to "prosy" poetry. However, while recognizing Appollinaire, Rimbaud, and Verhaeren's profound impact upon $\mathrm{Ai}$, Niu (like Payne) overlooks the influence of Whitman, whose free verse Ai so sincerely admired. We can now identify what Ai meant when he said that Whitman, Verhaeren, and Mayakovsky were bringing poetry into a newer realm and onto a higher plane. The newness in the poetry of Whitman, Mayakovsky, Guo, and Neruda is in fact the prose element they all employ. The newer realm and higher plane, then, is a reformed domain of poetry in which the older and listless forms are resuscitated by a timely injection of new "prosy" blood that rejuvenated poetry. This strong and liberating element is what Ai heard in Whitman when he wrote to Neruda that "no one would forget Whitman as a tall oak tree standing ingenuously on the earth and roaring night and day." 24

Kutztown University of Pennsylvania

\section{NOTES}

1. Quoted in Li Yeguang, "Walt Whitman in China," in Gay Wilson Allen and Ed Folsom, eds., Walt Whitman and the World (Iowa City: University of Iowa Press, 1995), 426. 
2. Ai Qing, An Appreciative Companion to Ai Qing's Famous Poems, ed. Niu Han and Guo Baochen (Beijing: China Peace Publishing House, 1993), 62; in Chinese. Hereafter abbreviated Famous Poems. All Chinese to English translations are mine.

3. Sun Yushi, "The Forgotten Song," in Famous Poems, 65.

4. Eugene Chen Eoyang, "Ai Qing, A Poet of the People," in Eoyang, ed., Selected Poems of Ai Qing (Bloomington: Indiana University Press [in association with the Foreign Languages Press, Beijing], 1982), i-ii.

5. Whitman, Complete Poetry and Collected Prose (New York: Library of America, 1996), 5-6.

6. Eoyang, v.

7. Tian Han, "Poet of the Common People," Young China 1 (July 1919), 6-21; in Chinese.

8. Wang Nan, "International Conference on Ai Qing's Works Held in Beijing," People's Daily (Overseas Edition), August 26, 1991; in Chinese.

9. Eoyang, vi.

10. Whitman, Poetry and Prose, 9.

11. Liu Shusen, "A Review of the History and Current Status of Whitman Studies in China," Social Sciences Information from Higher Education Institutions 2 (1991), 27; in Chinese.

12. Etienne Balibar and Pierre Macherey, "Literature as an Ideological Form," in Philip Rice and Patricia Waugh, eds., Modern Literary Theory (London: Edward Arnold, 1992), 65, 68.

13. Ai, Famous Poems, 258.

14. Ai, Famous Poems, 322.

15. Whitman, Poetry and Prose, 297.

16. Ai, Famous Poems, 324.

17. Quoted in Li Yang, "Ai Qing and Modern Euro-American Literature and Arts," Red Rock 2 (1981), 152-159; in Chinese.

18. Ai, Famous Poems, 157, 159.

19. Robert Payne, "Introduction," in Payne, ed., Contemporary Chinese Poetry (London: Routledge, 1947), 24.

20. Zhou Hongxing, "The Artistic Achievements of Ai Qing's Poetry," in Famous Poems, 476 .

21. Niu Han, preface to Famous Poems, 4-5.

22. Ai, Famous Poems, 16.

23. Payne, 21.

24. Quoted in Li Yeguang, 426. 